\title{
Medication Adherence to Antiretroviral Therapy Among Patients Visiting Antiretroviral Therapy Center at Tribhuvan University Teaching Hospital, Kathmandu, Nepal
}

\author{
Sharma $\mathrm{S},{ }^{1}$ Khadga $\mathrm{P},{ }^{1}$ Dhungana $\mathrm{GP},{ }^{2}$ Chitrakar $\mathrm{U}^{3}$
}

${ }^{1}$ Department of Medicine, Tribhuvan University Teaching Hospital, Maharajgunj, Kathmandu, Nepal

2Department of Microbiology, Tribhuvan University, Shree Siddhanath Science Campus, Mahendranagar Kanchanpur, Nepal

${ }^{3}$ Department of Nursing, Tribhuvan University Teaching Hospital, Maharajgunj, Kathmandu, Nepal

Corresponding Author

Sashi Sharma

Department of Medicine and Chief of HIV/AIDS Unit

Tribhuvan University Teaching Hospital

Maharajgunj, Kathmandu, Nepal

E-mail: drsashi19@hotmail.com

Citation

Sharma S, Khadga P, Dhungana GP, Chitrakar U. Medication Adherence to Antiretroviral Therapy Among Patients Visiting Antiretroviral Therapy Center at Tribhuvan University Teaching Hospital, Kathmandu, Nepal. Kathmandu Univ Med J 2013;41(1):50-53.

\section{ABSTRACT}

\section{Background}

Although antiretroviral therapy has limited efficiency, patients should take multiple drugs in combination in prescribed time for lifelong and they should also require specific food and fluid restriction. Due to these and other factors patients may discontinue their medication and therefore face significant challenges in adherence.

\section{Objectives}

To assess factors associated with non-adherence among people living with HIV receiving the antiretroviral therapy.

\section{Methods}

Between July 2011 to January 2012, a cross sectional survey was conducted among patients visiting HIV/AIDS unit, Tribhuvan University Teaching Hospital for therapy. After taking informed consent, a pre-structured questionnaire was filled up and data were entered into SPSS 11.5 system and analyzed.

\section{Results}

Of the 100 studied subjects, 61 (61.0\%) were male and 39 (39\%) were female. Adherence was found to be $79 \%$. The major barrier to adherence was reported to be simply forgetfulness (33.3\% of those non adherents). Non adherence was significantly associated with types of family ( $X^{2}$ value, 7.11$)$, smoking $\left(X^{2}\right.$ value, 5.44$)$ and alcoholic habit ( $X^{2}$ value, 5.69) but not with gender ( $X^{2}$ value, 2.57$)$. Besides this, poor economic status, and attendance to religious ceremony were reported to be major obstacles to adherence.

\section{Conclusion}

Adherence at this center was found to be only satisfactory. Forgetfulness was reported to be the major cause of non adherence. Persons living in joint family and those with alcoholic and /or smoking habit were more likely to miss the pills. It can be recommended that effective counseling, moral/financial support for HIV/AIDS patients may increase their adherence.

\section{KEY WORDS}

Adherence, HIV/AIDS, Kathmandu

\section{INTRODUCTION}

Nepal is described as having a "concentrated" HIV/AIDS epidemic. ${ }^{1}$ About 64,000 people are estimated to be infected with HIV in Nepal and as of 15 December, 2011 the reported cases were 19,118 (National Center for AIDS and STI control, NCASC). ${ }^{2}$

In order for antiretroviral therapy (ART) to be effective, patients must adhere strictly to an often demanding treatment regimen. ${ }^{3}$ Adherence is defined as the patient's ability to follow treatment plan by taking the correct dose of medications, at prescribed time and frequencies (on schedule), and following dietary instructions. ${ }^{4}$

Poor adherence is linked to the development of drug resistance, higher mortality rates, lower rates of increase in CD4 cell count, lower rates of undetectable viral load, lower therapeutic success and increased hospital stays. ${ }^{5,6}$ It has been estimated that at least $95 \%$ adherence with therapy is required to maintain HIV viral suppression. ${ }^{7}$ Reasons reported for non-adherence in African studies 
include forgetting, travel, fear of disclosure, shortage of pills, difficult schedules, cost, lack of access and privacy. ${ }^{8}$ In case of Nepal, travel cost was reported to be the significant barrier to adherence to ART. ${ }^{9}$

If this issue is not addressed timely it could arise as a major obstacle in long term management of HIV/AIDS patients undertaking ART. So far, in Nepal there are only limited studies on major barriers to ART adherence among HIV/ AIDS patients. Therefore, an attempt was made to assess factors associated with non-adherence among people living with HIV receiving ART at Tribhuvan University Teaching Hospital (TUTH), Maharajgunj, Kathmandu, Nepal.

\section{METHODS}

A cross sectional survey of analytical type was conducted from July 2011 to January 2012 among HIV/AIDS patients undergoing ART at Tribhuvan University Teaching Hospital. Patients were recruited by consecutive sampling method. A pre-structured questionnaire was designed. It contained three sections: Personal Information, ART/CD4 related information and Adherence related information. All patients who were willing to give informed consent were included in the study. In case of children, the data were collected from their guardians. Thus obtained information were entered into SPSS 11.5 and analyzed.

\section{RESULTS}

Of the 100 studied subjects, 61 (61.0\%) were male and 39 $(39 \%)$ were female. Majority of the respondents were in the age group $31-50$ years (62\%). $43.0 \%$ of the respondents were unemployed followed by farmers and businessmen. $45.0 \%$ of them were illiterate and $64.0 \%$ acquired HIV infection by sexual means (Table 1 ).

Adherence was low (<95\%) in $21(21 \%)$ patients i.e. only $79 \%$ of the patients did not miss or delay the ART regimen. The major barrier to adherence was reported to be simply forgetfulness (33.3\% of those non adherents). The nature of forgetfulness was reported as busy working hours, talking with friends/relatives, ignorance, unavailability of special devices/persons to remind in time etc. Besides this, poor economic status, alcohol use and attendance to religious ceremony were reported to be major obstacles to adherence (Fig 1).

Non adherence to ART regimen was significantly associated with types of family, smoking and alcoholic habit but not with gender. Both the illiterate and literate subjects had missed the ART pills. Non adherence was comparatively higher in children (age group 1-20 years) and elderly person (age group 51-60 years). Among patients who missed the regimen, $61.9 \%$ showed increased in weight where as it was $74.7 \%$ for those patients who have not missed the regimen and similar trend could be observed for the increase in CD4 count (table 2).
Table 1. Socio-demographic characteristics of studied subjects .

\begin{tabular}{|c|c|c|c|}
\hline Characteristics & Male & Female & Total \\
\hline \multicolumn{4}{|l|}{ Age group (Yrs) } \\
\hline 1-10 & $9(14.8)$ & $5(12.8)$ & $14(14.0)$ \\
\hline $11-20$ & $1(1.6)$ & $2(5.1)$ & $3(3.0)$ \\
\hline $21-30$ & $3(4.9)$ & 6(15.4) & $9(9.0)$ \\
\hline $31-40$ & $25(41.0)$ & $16(41.0)$ & $41(41.0)$ \\
\hline $41-50$ & $14(23.0)$ & $7(17.9)$ & $21(21.0)$ \\
\hline $51-60$ & $9(14.8)$ & $2(5.1)$ & $11(11.0)$ \\
\hline $61-70$ & 0 & $1(2.6)$ & $1(1.0)$ \\
\hline Total & $61(100)$ & $39(100)$ & $100(100)$ \\
\hline \multicolumn{4}{|l|}{ Marital status } \\
\hline Married & $41(67.2)$ & $21(53.8)$ & $62(62.0)$ \\
\hline Unmarried & $18(29.5)$ & $8(20.5)$ & $26(26.0)$ \\
\hline Widowed & $1(1.6)$ & $10(26.6)$ & $11(11.0)$ \\
\hline Divorced & $1(1.6)$ & 0 & $1(1.0)$ \\
\hline Total & $61(100)$ & $39(100)$ & $100(100)$ \\
\hline \multicolumn{4}{|l|}{ Educational level } \\
\hline Illiterate & $21(34.4)$ & $24(61.5)$ & $45(45.0)$ \\
\hline Primary & 10(16.4) & $8(20.5)$ & $18(18.0)$ \\
\hline Lower secondary & $4(6.6)$ & $2(5.1)$ & $6(6.0)$ \\
\hline Secondary & $20(32.8)$ & $3(7.7)$ & $23(23.0)$ \\
\hline Higher secondary & $4(6.6)$ & $1(2.6)$ & $5(5.0)$ \\
\hline $\begin{array}{l}\text { Bachelor and } \\
\text { above }\end{array}$ & $2(3.3)$ & $1(2.6)$ & $3(3.0)$ \\
\hline Total & $61(100)$ & $39(100)$ & $100(100)$ \\
\hline \multicolumn{4}{|l|}{ Occupation } \\
\hline Unemployed & $21(34.4)$ & $22(56.4)$ & $43(43.0)$ \\
\hline Farming & $11(18.0)$ & $7(17.9)$ & $18(18.0)$ \\
\hline Business & $13(21.3)$ & $5(12.8)$ & $18(18.0)$ \\
\hline Service & $10(16.4)$ & $4(10.3)$ & $14(14.0)$ \\
\hline Volunteer & $4(6.6)$ & 0 & $4(4.0)$ \\
\hline Student & $2(3.3)$ & $1(2.6)$ & $3(3.0)$ \\
\hline Total & $61(100)$ & $39(100)$ & $100(100)$ \\
\hline \multicolumn{4}{|c|}{ Mode of HIV infection } \\
\hline Sexual & $32(52.5)$ & $32(82.1)$ & $64(64.0)$ \\
\hline Injecting drugs & $16(26.2)$ & 0 & $16(16.0)$ \\
\hline Mother to child & $10(16.4)$ & $7(17.9)$ & $17(17.0)$ \\
\hline Blood & $3(4.9)$ & 00 & $3(3.0)$ \\
\hline Total & $61(100)$ & $39(100)$ & $100(100)$ \\
\hline
\end{tabular}

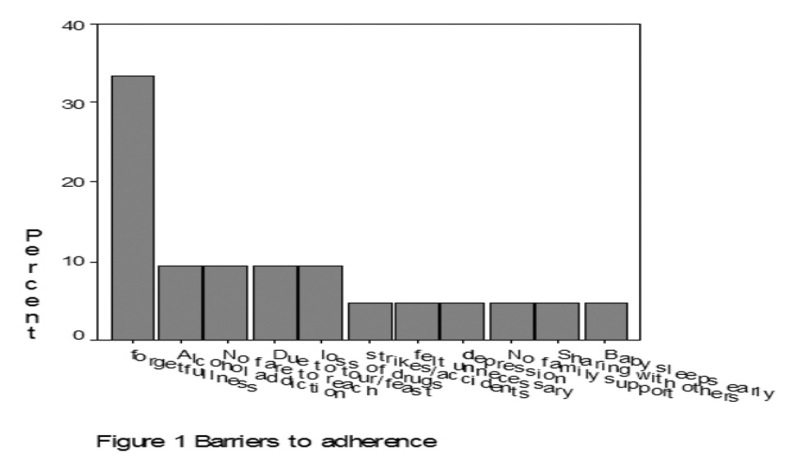

Figure 1. Barriers to adherence. 
Table 2. Relationship between Missing of ART regimen and relevant features.

\begin{tabular}{|c|c|c|c|c|c|}
\hline \multirow[t]{2}{*}{ Features } & & \multicolumn{3}{|c|}{ Missing } & \multirow[t]{2}{*}{$X^{2}$ values } \\
\hline & & Yes & No & Total & \\
\hline \multirow[t]{3}{*}{ Gender } & Male & 16 & 45 & 61 & \multirow{3}{*}{$\begin{array}{l}2.57 \\
\text { (Not signifi- } \\
\text { cant) }\end{array}$} \\
\hline & Female & 5 & 34 & 39 & \\
\hline & Total & 21 & 79 & 100 & \\
\hline \multirow{3}{*}{$\begin{array}{l}\text { Family } \\
\text { type }\end{array}$} & Joint & 15 & 48 & 63 & \multirow{3}{*}{$\begin{array}{l}7.11 \\
\text { (Significant) }\end{array}$} \\
\hline & Nuclear & 6 & 31 & 37 & \\
\hline & Total & 21 & 79 & 100 & \\
\hline \multirow[t]{3}{*}{ Smoking } & Yes & 8 & 12 & 20 & \multirow{3}{*}{$\begin{array}{l}5.44 \\
\text { (Significant) }\end{array}$} \\
\hline & No & 13 & 67 & 80 & \\
\hline & Total & 21 & 79 & 100 & \\
\hline \multirow{3}{*}{$\begin{array}{l}\text { Alcohol } \\
\text { addiction }\end{array}$} & Yes & 6 & 7 & 13 & \multirow{3}{*}{$\begin{array}{l}5.69 \\
\text { (significant) }\end{array}$} \\
\hline & No & 15 & 72 & 87 & \\
\hline & Total & 21 & 79 & 100 & \\
\hline \multirow{3}{*}{$\begin{array}{l}\text { Educa- } \\
\text { tional } \\
\text { level }\end{array}$} & Illiterate & $9(20)$ & $36(80)$ & 45 (100) & \\
\hline & Literate & $12(21.8)$ & $43(78.2)$ & $55(100)$ & \\
\hline & Total & $21(21.0)$ & $79(79.0)$ & $100(100)$ & \\
\hline \multirow[t]{8}{*}{$\begin{array}{l}\text { Age } \\
\text { group }\end{array}$} & $1-10$ & $4(28.5)$ & $\begin{array}{l}10 \\
(71.5)\end{array}$ & $14(100)$ & \\
\hline & $11-20$ & $1(33.3)$ & $2(66.7)$ & $3(100)$ & \\
\hline & $21-30$ & $2(22.2)$ & $7(77.8)$ & $9(100)$ & \\
\hline & $31-40$ & $7(17.0)$ & $\begin{array}{l}34 \\
(82.9)\end{array}$ & $41(100)$ & \\
\hline & $41-50$ & $4(19.0)$ & $17(81.0)$ & $21(100)$ & \\
\hline & $51-60$ & $3(27.2)$ & $8(72.7)$ & $11(100)$ & \\
\hline & $61-70$ & 0 & $1(1.3)$ & $1(1.0)$ & \\
\hline & Total & $21(100)$ & $79(100)$ & $100(100)$ & \\
\hline \multirow[t]{3}{*}{$\begin{array}{l}\text { Increase } \\
\text { in weight }\end{array}$} & Yes & $13(61.9)$ & $\begin{array}{l}59 \\
(74.7)\end{array}$ & $72(72.0)$ & \\
\hline & No & $8(38.1)$ & $20(25.3)$ & $28(28.0)$ & \\
\hline & Total & $21(100)$ & $79(100)$ & $100(100)$ & \\
\hline \multirow{3}{*}{$\begin{array}{l}\text { Increase } \\
\text { in CD4 }\end{array}$} & Yes & $14(66.7)$ & $57(72.2)$ & $71(71)$ & \\
\hline & No & $7(33.3)$ & $22(27.8)$ & $29(29)$ & \\
\hline & Total & $21(100)$ & $79(100)$ & $100(100)$ & \\
\hline
\end{tabular}

\section{DISCUSSION}

Adherence level at TUTH, Kathmandu was found to be lower than that reported from ART centers of far west Nepal. Similar study conducted in four ART centers of far western Nepal during mid 2009 had reported that the overall adherence rate was $84 \% .{ }^{9}$ Low adherences in Kathmandu in comparison to far western region might be due to busy urban life, frequent strikes (that may affect transportation as more people living with HIV/AIDS depend on public vehicles to reach the ART site). Furthermore, many ART patients are out of Kathmandu and this could be one of the reasons for low adherence. Adherence rate in TUTH was lower than that reported in Lok Nayak Jai
Prakash (LNJP) hospital where it was found to be as high as $90 \%$ but the rate was higher than that reported in All India Institute of Medical Sciences (AIIMS) where it was only $47 \% .{ }^{10}$ Adherence rate at TUTH was found to be nearly same as The AIDS Support Organization (TASO Clinic), Kampala, Uganda where the rate was $78.2 \%{ }^{11}$

Our findings that forgetfulness as the major cause of non adherence is consistent with other similar studies. A study conducted at Yirgalem Hospital, South Ethiopia documented that the main reason for non adherence was forgetting (51\% of those non-adherents). ${ }^{12}$ Our study showed that alcohol addiction, poor economic status (for e.g. lack of transportation fare to reach the ART site) and social norm of attending family rituals were the major barriers to ART adherence. Similar results were obtained by other studies. 13,14 Patients living in joint family were more likely to be non adherent than those living in single family and the relationship was statistically significant. Similar results were obtained with alcoholic and /or smoking habits. However, no relationship could be established between gender and adherence rate (table 2). These findings were also found to be consistent with the results obtained from previous studies in western setting of Nepal and other similar studies elsewhere. ${ }^{9,15-17}$ One of the limitations of this study is that its finding are based on the information given ART follow up cases of TUTH and may or may not represent national scenario. Therefore, more extensive studies are recommended to generate more convincing data.

\section{CONCLUSION}

Adherence to ART at this center was found to be only satisfactory in comparison to other studies in Nepal and elsewhere. Forgetfulness was reported to be the major cause of non adherence. Persons living in joint family and those with alcoholic and /or smoking habit are more likely to miss the regimen. Besides these, poor economic status, busy working hours and social norms to attend religious rituals were reported to be major obstacles to adherence On the basis of this study it can be recommended that effective counseling; moral/financial support for HIV/AIDS patients may increase their adherence to ART. Therefore, concrete steps should be taken to increase the adherence rate which could be helpful for the long term management of HIV/AIDS patients undergoing ART.

\section{ACKNOWLEDGEMENTS}

We would like to express sincere thanks to all the PLWHA volunteers for participating in this study. We are equally thankful to all the staffs of HIV/AIDS unit TUTH, especially Madhav Pant and Mina Shrestha. 


\section{REFERENCES}

1. Suvedi BK. Transition of HIV epidemic in Nepal. Kathmandu Univ Med J 2006 Jan-Mar;4(1):115-118.

2. National Center of AIDS and STI control (NCASC). Cumulative HIV/ AIDS situation in Nepal (Fact sheet). NCASC, Teku, Kathmandu.

3. RS Braithwaite, Bryant KJ. Influence of alcohol on adherence to and toxicity of antiretroviral therapy and survival. Alcohol Research and Health 2020, 33(3):280-287.

4. Castro A. Adherence to antiretroviral Therapy: Merging the clinical and social course of AIDS. PLOS Med 2005;2(12):338.

5. Hogan D, Salomon J et al; Prevention and treatment of HIV/AIDS in resource limioted settings. Bulletin of WHO.2005 Feb;83(2).

6. Stone VE. Strategies for optimizing adherence to highly active antiretroviral therapy. Lessons from research and clinical practice. Clinical Infectious diseases 2001;33:865-872.

7. Paterson DL, Swindells S, Mohr J, Brewster M, Vergis EN et.al. Adherence to Protease Inhibitor and Outcomes in Patients with HIV Infection. Annals of Internal Medicine 2000;133(1): 21-30.

8. Day J, Godoka N, Nyamafeni P, Chigwanda M. Adherence to ART in clinical trial settings in Zimbabwe and Uganda: Lessons learned; Bangkok, Thailand .International Conference AIDS 2002 Jul;15: 11-16.

9. Bam K, Karki DK, Lohani SP, Thapa R, Aryal UR, Pathak LR. Adherence to antiretroviral therapy among people living with HIV and AIDS in far west , Nepal. Asian Journal of Medical Sciences 2011;2:7-13.

10. Lal V, Kant S, Dewan R, Rai Sk, Biswas A. A two-site hospital-based study on factors associated with nonadherence to highly active antiretroviral therapy. Indian J public Health 2010;54(4):179-183.
11. Abaasa AM, Todd J, Ekoru K, Kalyango JN, Levin J, Odeke E et.al. Good adherence to HAART and improved survival in a community HIV/ AIDS treatment and care programme: the experience of The AIDS Support Organization (TASO), Kampala, Uganda. BMC Health Serv Res $2008 ; 20 ; 8: 241$.

12. Markos E, Worku A, Davey G. Adherence to ART in People Living with HIV/AIDS at Yirgalem Hospital, South Ethiopia. Ethiop.J.Health Dev 2008;22(2):174-179.

13. Joglekar N, Paranjape R, Jain R, Rahane G, Potdar R, Reddy KS et.al. Barriers to ART adherence $\&$ follow ups among patients attending ART centers in Maharashtra, India. India J Med Res 2011 134(6):954-9.

14. Sanjobo N, Frich JC, Fretheim A. Barriers and facilitators to patients' adherence to antiretroviral treatment in Zambia: a qualitative study. SAHARA J 2008 Sep;5(3):136-143.

15. Mothashari F, Riley E, Selwyn PA, Altice F. Acceptance and adherence with antiretroviral therapy among HIV-infected women in correctional facility. Journal of Acquired Immune Deficiency Syndromes and Human Retrovirology 1998;18: 341-348.

16. Morse EV , Simon PM , Coburn M, Hyslop N , Greenspan D, Balson PM. Determinants of subject compliance with an experimental antiHIV drug protocol. Social Science and Medicine 1991;32: 1161- 1167.

17. Pinheiro CA , De-Carvalho-Leite JC, Drachler ML, Silveira VL. Factors associated with adherence to antiretroviral therapy in HIV/AIDS patients: a cross-sectional study in Southern Brazil. Braz J Med Biol Res 2002; 35:1173-1181. 